\title{
Partial Privatization and Firm Performance: Evidence from India
}

\author{
By: Nandini Gupta
}

William Davidson Working Paper Number 426

December 2001 


\title{
Partial Privatization and Firm Performance: Evidence from India*
}

\author{
Nandini Gupta ${ }^{\dagger}$ \\ December 2001 \\ Preliminary and Incomplete
}

\begin{abstract}
Privatization in India has been limited to the diffuse sale of minority stakes in firms. Since control rights have not been transferred to private owners it is widely contended that the process has had little impact on firm behavior. We find however that even the sale of minority stakes has a positive impact on firm performance and productivity. As the government remains the controlling owner in these firms, we infer that the improvement is attributable to the role of the stock market in monitoring managerial performance rather than to a change in owners' objectives. Consistent with this interpretation, we find that improvements in earnings are due to an increase in the productivity of labor rather than layoffs. Partial privatization continues to affect the sales and operating efficiency of firms when we control for competitive conditions, and the evidence also suggests that privatization and competition have a complementary impact on firm performance.
\end{abstract}

${ }^{*}$ I would like to thank Pierre Azoulay, Serdar Dinc, Sugato Bhattacharyya, Klara Sabirianova, and Jan Svejnar. I am particularly grateful to the Administrative Staff College of India for providing some of the data used in this analysis and Nandini Lahiri for research assistance. This paper has also benefited from the comments of participants at the WDI India conference and University of Michigan Business School seminar. All remaining errors are mine.

${ }^{\dagger}$ The William Davidson Institute and the University of Michigan Business School, nandinig@umich.edu. 


\section{Introduction}

The economic transition of socialist economies and the trend towards privatization within both developing and developed market economies have generated a large empirical literature on the effect of ownership on firm performance. Most of these studies find that privatization has a positive impact on the profitability and efficiency of firms (see Megginson and Netter, 2001, for a recent survey). The firms in these studies have had a majority of their assets privatized and control rights have been transferred from the government to private owners. Surprisingly little is known about the effect of partial privatization in which control rights are not transferred, even though most privatization transactions of significant size are partial sales of equity often through the stock market. This paper uses information on the fraction of equity sold through partial privatizations in India to investigate whether the performance of government-owned firms is affected by the sale of minority stakes.

In a sample of 630 privatization offers from 59 countries, Jones, Megginson, Nash, and Netter, (1999) find that an average of $36.8 \%$ of capital is sold in these offers, with less than $8 \%$ of the firms selling a $100 \%$ of their capital. India's privatization program too has proceeded slowly with an average of 16 percent of equity in 44 of 258 centrally-owned firms sold in the ten years following the adoption of the privatization policy in 1991. ${ }^{1}$ Through 1999 the government had raised only about $\$ 4$ billion according to the Department of Disinvestment (2001), ${ }^{2}$ and South Asia's share of total privatization revenues raised by developing countries was just 4 percent in 1999, while Latin America and the Caribbean accounted for 54 per cent (World Bank, 2001). The pace has picked up slightly in recent years with five firms being sold to strategic partners in the last two years ${ }^{3}$ but sale of non-controlling shares remains the primary method of privatization.

The theoretical literature on privatization considers two types of problems associated with government ownership: the political problem that political interference distorts the objectives and constraints faced by managers (Shleifer and Vishny, 1994) and the managerial problem that poor monitoring leads to low-powered incentives among managers (Vickers and Yarrow,

\footnotetext{
${ }^{1}$ The total number of firms includes both financial and non-financial firms.

${ }^{2}$ The World Bank reports $\$ 8.83$ billion in privatization revenues between 1991 and 1999 (World Bank, 2001).

${ }^{3}$ These are Modern Foods and Lagan Jute Machinery (74\% stake in each sold in 2000), Bharat Aluminium Company, Computer Maintenance Corporation (51\% stake in each sold in 2001) and Hindustan Teleprinters Limited (74\% stake sold in 2001).
} 
1989). ${ }^{4}$ In firms that have been fully privatized it is difficult to identify whether the observed improvements in firm performance occur because the new owners pursue profit maximization rather than other objectives, or because the new owners are better able to monitor managers. Partial privatization without transfer of control allows us to concentrate on the second possibility. The firm remains under government control and subject to political interference, but the trading of shares on public stock markets provides current information on the firm's performance as judged by market participants. This information can be used by the state to better monitor the managers, and can also be used by managers in the executive job market as a public signal of their performance.

India's adoption of the disinvestment policy was accompanied by two other policies that allow us to investigate the relative effects of privatization and competition. "Dereservation" eliminated restrictions on private entry into all but 4 out of 17 sectors that used to be reserved for the public sector. At the same time, restrictions on foreign equity investments were liberalized in all but a few sectors of the economy. While some have argued that manager incentives can be shaped better by competition (Vickers and Yarrow, 1989), others argue that so long as public sector firms are characterized by political interference and poor governance, inefficiencies cannot be fully addressed by increased competition (Shleifer and Vishny, 1997). By controlling for changes in competitive conditions we are also able to ensure that changes in firm behavior are not incorrectly attributed to privatization.

We observe firm level panel data on the population of non-financial public sector firms owned by the central (federal) government of India, accounting for approximately 85 percent of the overall assets of non-financial firms owned by the state and central governments. We observe the pre and postprivatization performance of all 36 firms privatized by the central government upto $1998 .{ }^{5}$ The data extends for nine years starting from 1990, the year prior to the economic reforms undertaken in 1991. We also include about 44 manufacturing and non-financial service sector firms owned by regional governments. The accounting information was compiled from annual income statements and has been used recently by Bertrand, Mehta, and Mullainathan (2001), among others. We supplement this data with information on employment from annual surveys of public enterprises published by the government, and with information on privatization transactions for each firm obtained from newspaper reports, government sources, and the World

\footnotetext{
${ }^{4}$ LaPorta and Lopez-di-Silanes (1999) also use this categorization.

${ }^{5}$ We also observe the pre-privatization performance of the 8 firms sold since 1998 .
} 
Bank. We have information on the fraction of equity sold in each firm in a given year. The effect of market reforms on firm performance is captured by the two policy measures described earlier: dereservation, where after nearly forty years of protection, 13 out of 17 protected sectors were opened to domestic and foreign private participation; and liberalization, which allowed for automatic approval of foreign participation in certain sectors.

Comparing the mean performance of firms in the years prior to the first tranche of partial privatization to average performance in the years following the first tranche, we find significant differences in revenues, labor productivity, and the share of government loans in the total borrowings of firms. Compared to average performance in the prior years, sales and profits increase by 59 percentage points and 22.6 percentage points respectively, and the fraction of loans financed by the government declines by 5.8 percentage points. On the other hand employment does not appear to change significantly after partial privatization. To control for firm-specific and macroeconomic factors that could account for performance change, we also estimate firm fixed effects specifications to investigate the average impact of partial privatization on firm performance, using firms that remain wholly owned by the government as the control group. We find that a 10 percentage point decrease in the share of government equity would increase sales by 27 percentage points, profits by 15 percentage points, average product of labor (sales over labor) by 6 percentage points, and returns to labor (operating income over employment) by 8 percentage points. However, there is no accompanying decline in employment.

The results also indicate that partial privatization continues to have a significant impact on firm performance when we control for competitive conditions. Firms in sectors that were previously reserved for the government are found to react favorably to dereservation as seen by significantly higher sales revenues and profits. On the other hand we find that liberalizing restrictions on foreign participation has an adverse impact on sales. Unlike privatization, changes in competitive conditions do not appear to affect productive efficiency as measured by the average product of labor and returns to labor. However competitive pressures do have an impact on allocative efficiency since they appear to reduce employment. These results suggest that improvements in firm performance can be brought about through a combination of privatization and competition enhancing policies.

We also find evidence that the share of government loans in total borrowing has a statistically significant and negative impact on both sales and profits which is consistent with the view that the government may use loans to pursue objectives other than profit maximization. However, it does not 
appear that soft budget constraints affect the level of employment in these firms. ${ }^{6}$

The fixed effects specification takes into account selection bias arising out of time invariant unobservable factors that affect performance, such as would occur if more profitable or larger firms are selected for privatization. In the estimations we also include firm specific controls and year dummies to control for contemporaneous macroeconomic shocks. To the extent that selection may be dynamic, as when firms are being sold because they have better management or they are able to adjust better to market reforms, and these characteristics are unobservable (to the researcher) and shifting over time, fixed effects estimates would be inconsistent. It is difficult to identify and correct for all such effects, however we use a number of approaches that potentially address this issue. First, we investigate the impact of the fraction of equity sold on the performance of privatized firms in a given year where the control group consists of firms that have been selected for privatization in later years. Frydman et al. (1999) argue that the control group of firms would share similar unobservable characteristics that materialize over time hence this method would potentially address dynamic selection. We find that the results reported earlier do not change. Second, like Bartel and Harrison (2001) we compare the pre-privatization performance of firms to firms that are not privatized to check whether there is selection based on unusually good or bad performance just prior to privatization which could lead to under or overestimation of the effect of privatization (Ashenfelter, 1978), and again do not find evidence of selection. Third, we estimate all specifications excluding the oil and gas companies which are arguably the most profitable and have the greatest potential in terms of future profitability among the state-owned firms, and find that the results remain similar.

In the next section we describe the main characteristics of India's economic reforms and its public sector. Following this we briefly discuss the theory on ownership and empirical implications for the data. Sections 4 and 5 describe the data, results, and potential problems with the estimation strategy that we address. We conclude and discuss extensions in Section 6 .

\section{Background of the Indian privatization program}

In response to a foreign exchange crisis in 1991, India undertook sweeping economic reforms which included deregulation and privatization. Since the

\footnotetext{
${ }^{6}$ However soft budget constraints do have a significant negative impact on employment as we shall see in Section 5.3 below, when we consider a smaller sample of firms.
} 
Industrial Policy Resolution of 1991 which outlined the economic reforms, the privatization goal declared in every government's annual budget is to reduce government ownership to 26 per cent of equity in all non-strategic firms. ${ }^{7}$ Euphemistically referred to as "disinvestment", privatization has proven to be the most difficult to implement of all the reforms. To date the disinvestment process in firms owned by the federal government has consisted of the sale of an average of 16 per cent of equity in 44 firms out of 258 financial and non-financial firms, including the strategic sale of three firms between 1999 and 2001 and the approval of another five firms in late $2001 .^{8}$ There were 14 rounds of disinvestment between 1991 and 2000 through which the government raised about $\$ 4$ billion in revenues (Department of Public Enterprises, 2001 and Department of Disinvestment, 2001). In the first round in 1991 and 1992 the government raised $\$ 638$ million in revenues through the sale of between 5 and 20 per cent of equity in 31 firms. ${ }^{9}$ Bundles of shares in these firms were sold mainly to domestic financial institutions. In response to allegations that shares had been sold at too low a price in the first round, bundling of shares was abandoned and shares of each company were sold by auction between 1992 and 1993. In 1994 the government permitted the participation of foreigners, and in the disinvestments of 1996-1999, firms in the telecommunications, oil, and construction sectors were sold via global depository receipts in international markets in addition to sales in domestic capital markets. A controversial event of the disinvestment process was the purchase of equity in state-owned companies by other state-owned companies in 1999. Our data includes privatization transactions between 1991 and 1998, hence we do not consider firms that sold equity to other state-owned firms nor do we observe the full privatization of three companies between 1999 and 2001. We have also checked stock-market participation among the partially privatized firms in our sample and find that with the exception of 2 firms, all the other privatized firms in our sample are listed with their shares being traded on the stock market since they were privatized, and not prior to that. The remaining 2 firms are owned by state governments and are not publicly traded.

Large-scale government ownership of firms in India was originally justified by concerns that the private sector would not undertake projects requiring large investments with long gestation periods. Starting in the late 1960s

\footnotetext{
${ }^{7}$ Strategic firms are those in the defense, atomic energy, and railway sectors. $26 \%$ is the minimum amount of equity necessary for some certain voting powers.

${ }^{8}$ Our data ends in 1998 and we observe all 36 firms sold by the central government upto that year.

${ }^{9}$ Rs 30.38 billion converted at Rs $47=\$ 1$ into current dollars.
} 
there was a period of rapid nationalization of firms in all sectors, so that by the mid-seventies the public sector accounted for one-fifth of GDP and two-thirds of the total fixed capital invested in the economy (Goyal, 1999). The Indian public sector consists of departmental enterprises that are run directly by government ministries, such as the railways, the postal service, telecommunications, irrigation, and power, and enterprises that have separate boards of directors. At the end of 1992 there were 1180 firms in which the government was the majority owner, 941 of which were owned by state governments. However, firms owned by the central government account for nearly 85 per cent of the overall assets of state-owned companies. Over 42 per cent of the firms owned by the central government are in manufacturing, 28.62 per cent in mining, and nearly 20 per cent are utilities, while a third of state government firms are in manufacturing, with the remaining firms primarily concentrated in agriculture and finance (Goyal, 1999). Public sector firms are large employers, with 2 million workers employed in central government firms in the nineties, accounting for 10 per cent of the total workforce in the organized sector. ${ }^{10}$

The disinvestment program has not moved as fast as planned. So far control has been transferred in just three firms to private owners. Further, in every year except 1991 and 1998, disinvestment revenues have fallen short of the targets set by the government in its annual budget (in 1999 the government achieved just 18 per cent of its revenue target). Finally, the public sector remains unprofitable, with an average ratio of after-tax profits to net sales of $-4.38 \%$ in public sector manufacturing enterprises between 1991 and 1997 compared to $6.65 \%$ for private sector manufacturing firms (Department of Disinvestment, 2001). Nearly half the public sector enterprises owned by the federal government are loss-making. In the government's own words, privatization would help in: "releasing huge amounts of scarce public resources locked up in non-strategic PSEs (public sector enterprises) for deployment in areas such as public health, education, etc.; stemming the further outflow of scarce public resources for sustaining the unviable enterprises; reducing public debt; transferring the commercial risk, to which tax-payers' money is exposed, to the private sector; releasing other tangible and intangible resources, such as, large manpower currently locked up in managing PSEs, for redeployment in areas that are much higher on the social priority" (Department of Disinvestment, 2001).

\footnotetext{
${ }^{10}$ The total workforce in the organized sector (registered companies) was estimated at 27 million in 1997, with 20 million employed in central and state governments, and government enterprises (Department of Disinvestment, 2001).
} 
Prior to 1991 India had an elaborate regulatory framework which involved restrictions on who could invest, how much, in what, and where. Despite the licensing requirements, ${ }^{11}$ the foreign ownership restrictions, and the restrictions on monopolistic business practices, not a single violation of any of these regulations was prosecuted in four decades. Instead, rampant rent-seeking led to an inefficient use of resources to circumvent the numerous regulations. While deregulation started in the mid-seventies, it was not until 1991 that most of the restrictions on business practices were removed. The main deregulatory measures undertaken in 1991 that affected the public sector were those allowing private sector participation in sectors previously reserved for the government and dispensing with ceilings on foreign equity. Dereservation reduced the number of sectors reserved for the public sector from seventeen to four. Only arms and ammunition, atomic energy production, mining of minerals related to atomic energy, and railway transportation remain closed to the private sector. ${ }^{12}$ Since 1991 there have been a number of joint ventures between public sector companies in dereserved sectors and domestic and foreign companies, including the ventures between Indian Oil Company and Mobil; IBP (retailer for gas) and Caltex Petroleum; and Balmer \& Lawrie Freight Containers and Tectrans of Germany.

Another deregulatory measure, which we refer to as liberalization, was the automatic approval of foreign equity up to 74 per cent in certain sectors. ${ }^{13}$ Investors still have to obtain government approval in the following industries: coal and lignite; petroleum; alcohol; sugar; tobacco products; defense and aerospace equipment; hazardous chemicals; and drugs and pharmaceutical products.

Following these changes in entry restrictions there have been a number of domestic and foreign entrants in the energy and telecommunications sectors.

\footnotetext{
${ }^{11}$ The "license raj" referred to the process by which firms had to apply for licenses, or government approval, for a wide range of activities.

${ }^{12}$ The sectors reserved for the public sector which were opened to private participation are Iron and Steel; Heavy Castings and Forgings of Iron and Steel; Heavy Plant and Machinery for Iron and Steel; Hydraulic and Steam Turbines; Coal and Lignite; Mineral Oils; Mining of Iron Ore, Manganese, Chrome, Gypsum, Sulphur, Gold and Diamonds, Copper, Lead, Zin, Tin, Molybdnum, Wolfram; Aircrafts; Air Transportation; Ship Building; Telephones and Telephone Cables; Telegraphs and Wireless Apparatus; and, the Generation and Distribution of Electricity.

${ }^{13}$ At the 2-digit SIC level the industries that were liberalized are: Food; Cotton and other Textiles; Textile Products; Basic Chemicals except Petroleum and Coal; Rubber, Plastic, Petroleum and Coal Products; Metal Products; Machinery and Equipment; Transport Equipment; Mining Services; Basic metals; Medical Equipment; Construction; and Land and Water Transportation services. We use two and three digit SIC codes to identify liberalized and dereserved sectors.
} 
The foreign firms include Enron Corporation; Cogentrix; AES Transpower; Rolls Royce; Powergen; British Telecom; AT\&T; Deutsche Telekom; and Nippon Telegraph. In air transportation a number of domestic and foreign joint venture firms also entered the airline industry, although some of these firms eventually exited the market because of continuing government regulations that favored the state-owned domestic carrier. ${ }^{14}$

Other deregulation measures undertaken since 1991 include the removal of the industrial licensing system under which private sector investments had to be approved by the government; removal of restrictions on investments made by large business groups; removal of restrictions on industrial location; and removal of restrictions on the expansion of business groups. Finally, the government also removed quantity restrictions and reduced import tariffs in most sectors.

In our data we investigate the effect of partial privatization and also control for the effects of dereservation and liberalization.

\section{$3 \quad$ Theory and empirical implications}

Ownership structure should not matter if complete contracts can be written and enforced (Coase, 1960; Williamson, 1985; and Grossman and Hart, 1986). Public sector firms are generally argued to be less efficient than private sector firms (in relatively competitive markets) because of low-powered managerial incentives. There are two non-mutually exclusive perspectives on the causes of poor incentives (Laffont and Tirole, 1993). First, the political perspective argues that a government pursues multiple objectives and some of these objectives, unlike profit maximization, are hard to contract on. Ownership in this case makes a difference when unforeseen contingencies arise which are not in the contract between the manager and the government. Williamson (1985) argued that in this case public ownership may be preferable because a social welfare maximizing government could impose socially desirable outcomes, whereas it would have to bargain with a private firm. However, this advantage would disappear in the case of a non-welfare maximizing government (Sappington and Stiglitz, 1987). Moreover, in the presence of incomplete contracts, different government objectives can lead to expropriation of manager investments and result in suboptimal investment by managers ex ante (Laffont and Tirole, 1993). There may also be distor-

\footnotetext{
${ }^{14} \mathrm{~A}$ number of foreign firms have also exited the market recently as for example the high-profile pull-out of Enron in 2001 due to non-payment by its only customer, a local government entity.
} 
tions in the constraints of public sector managers because of the absence of a credible bankruptcy threat to these firms. Facing a soft budget constraint, managers have little incentive to cut costs. Soft budget constraints may also distort managerial incentives if the government uses loans to pursue objectives other than profit maximization. We test the political perspective by investigating whether government loans to firms can explain variation in firm performance.

In contrast, the managerial perspective on the advantage of private over public ownership argues that participation in the stock market gives managers better incentives by monitoring firm performance and gathering information on manager investments. As mentioned in the previous section, none of the shares of the Indian public sector firms in our sample were traded on the stock market prior to disinvesment. Since the extent of market liquidity affects the incentives of stock market participants to gather information on firms (Holmstrom and Tirole, 1993) we use data on partial sales of equity to investigate the theoretical implication that firm performance will depend on the fraction of equity sold. A question also arises as to why managers of public sector firms who, unlike their private sector counterparts, are not subject to an active market for corporate control would respond to increased monitoring of their performance. One reason could be the presence of a market for senior executives of public sector firms, particularly high performing public sector firms, who are in demand for their skills (Fama, 1980). A few public sector firms have remained without directors or CEOs for a number of years (Goyal, 1999). Disinvestment could also generate pressure on managers to maintain share value both from workers who are concerned about the possibility of layoffs once the firm is privately controlled and from the government which is concerned about revenues generated from future sales of equity in the firm. Finally, it can be argued that manager do not respond to increased monitoring but instead to the possibility of losing their jobs after the firm is transferred to private owners. However this argument does not provide an unambiguous impact on managerial incentives since managers could also deliberately worsen or misreport firm performance so as to discourage potential buyers and thereby keep their jobs.

One advantage of using data on privatization in India is that it allows us to investigate whether partial privatization mitigates firm inefficiency from the managerial perspective, since none of the firms we consider have been transferred to private owners. Given that nearly half of all public sector enterprises are loss making as of the year 2000, it would be difficult to argue that the government pursues a profit-maximization objective. Hence our empirical work also gives an estimate of the extent to which public sector 
inefficiency is due to low-powered manager incentives caused by inadequate monitoring of and information on managers.

To identify the effect of partial privatization on firm performance we also consider changes in the competitive environment of the firms. Liberalization and dereservation policies consitute a major part of the economic reforms since 1991, so variation in firm performance caused by increased competition may be mistakenly attributed to the disinvestment process. The debate on the relative importance of competition versus ownership focuses on the effect of competition on productive efficiency, since it is generally accepted that competition will induce allocative efficiency. Competition is said to affect managers' incentives because inefficient firms face reduced market share. Moreover, competition can also be an effective monitoring device because it facilitates performance comparisons (Hart, 1983). Vickers and Yarrow (1991) emphasize that efficiency gains from privatization will also depend on competition hence empirically the combined effect of the two policies are also of interest.

\section{Data}

We observe privatization status, industry, ownership status, and a range of accounting data for 341 manufacturing and service sector public firms owned by the central and state governments of India. This includes 249 firms that form the population of non-financial firms owned by the central government, and 92 firms that are owned by various state governments. We observe all the firms that were partially privatized by the central government until 1998. Firm level data is obtained from company balance sheets and annual income statements and have been collected by a private organization, the Centre for Monitoring the Indian Economy (CMIE). The panel consists of the years 1990-1998. We have at least a year of data prior to the economic reforms which were announced in 1991.

From the full sample we observe current sale revenues for an unbalanced panel of 2470 firm years between 1990 and 1998 (an average of 274 firms per year). Excluding firms that do not have information on lagged assets, the largest available sample for 1991 - 1998 is 2063 firm years (an average of 258 firms per year). ${ }^{15}$ This includes 284 firm years of observations for firms owned by regional governments. In order to avoid exacerbating attrition

\footnotetext{
${ }^{15}$ We do not have lagged observations for 1990. There are 220 firms in 1991, 231 firms in 1992, 228 in 1993, 240 firms in 1994, 244 firms in 1995, 270 firms in 1996, 281 firms in 1997 and 244 firms in 1998.
} 
bias we did not require a balanced panel.

While the data contains information on a wide range of income, cost and investment variables, it does not include ownership information except for the most current year reported for each firm. We supplement this data with information on privatization transactions from the Department of Heavy Enterprises, India, the World Bank Privatization Transactions Database, and from newspaper reports. The privatization information we collect includes the fraction sold of a firm, the year of sale, and the method of sale which generally consists of public offerings and global depository receipts. There are 36 firms in our sample that have been partially privatized with some firms being sold in more than one tranche. ${ }^{16}$

We obtain data on firm employment from the Annual Public Enterprise Survey published by the government. However, employment data is only available for a subset of the firms owned by the central government, reducing the sample size when we consider specifications that include employment.

Our data has a number of advantages over other studies that consider the effects of privatization. First, we have the population of non-financial public firms owned by the government of India. In terms of asset size, employment, market share, and political importance the central government owned firms form the bulk of state ownership in India. The study of privatization in Mexico by Laporta and Lopez-de-Silanes (1999) is the only other study to use the population of non-financial privatized firms. However, the key advantage of our data is that we also observe state-owned firms that were not privatized. Second, although data from the same source, CMIE, has been used in other contexts, this is the first to include data on employment and ownership for each year. Third, studies investigating the effect of privatization generally do not contain detailed ownership information such as the fraction sold, and hence are not able to capture the effect of variations in ownership (e.g. Frydman et al., 1999, only observe whether a firm has been privatized).

Table 1 reports the frequency distribution of privatization between 1991 and 1998 and the average fraction sold in each year. As seen in Table 1 the largest number of privatizations occurred in 1992, a year after the reforms were announced, with an average of $12 \%$ of shares of 26 firms being offered on the stock market. Table 1 also reports the number of firms in dereserved sectors and liberalized sectors.

\footnotetext{
${ }^{16} 11$ firms have undergone partial privatization in one tranche only.
} 


\section{$5 \quad$ Results}

We investigate the impact of partial privatization on the following broad measures of profitability and efficiency: sales, accounting profits, employment, average product of labor, and the returns to labor. The variables are described in the Appendix. Table 2 provides summary statistics for selected variables for 1991-1998 by ownership category.

From Table 2 it appears that partially privatized firms have higher sales, profits, labor, average product of labor, assets, and returns to labor than firms that remain state-owned. They also appear to receive a lower share of loans from the government compared to fully state-owned firms. Although the average characteristics of these firms is interesting, we need to establish whether the observed performance differences arise as a result of partial privatization. Table 3 presents before-after summary statistics of selected performance measures for firms that were privatized between 1991 and 1998. Since shares of some of the firms in our sample were sold in more than one tranche, we define the pre and post measures as average values of the variables for the years before and after the first tranche.

The descriptive statistics in Table 3 show that firms experience an increase in sales and profits after privatization. Sales are 59 percentage points higher on average after privatization, with the difference being significant at the 5 per cent level. Similarly, average profits are significantly higher in the years following the first tranche of privatization, registering an average increase of 22.6 percentage points. This increase in profitability is higher than found in similar studies. For example Laporta and Lopez-di-Silanes (1999), comparing the means of performance variables before and after privatization, find that the mean change in operating income to sales after privatization was 24.1 percentage points in their sample of Mexican firms.

Partial privatization does not appear to have much of an impact on the stock of fixed assets, reflecting the fact that public sector investments have been declining since 1991. It also appears that there is a significant decrease in the average share of government loans and subsidies in total borrowing after partial privatization.

The before-after estimator above relies on the assumption that among privatized firms the mean outcome in the years before privatization are the same as what would be the mean outcome in the years after in the absence of privatization. This assumption would be violated if, for example, there are changes in the overall state of the economy between these years, or if there are changes in the life-cycle position of some of these privatized firms. Below we use panel data to estimate a firm fixed effects specification which allows 
us to control for macroeconomic changes and estimate the average impact of private ownership by comparing partially privatized firms to those that remain state-owned throughout this period.

\subsection{Estimating the effect of partial private ownership}

While Table 3 compared the before after performance of firms that were partially privatized, we would like to investigate the average impact of privatization, and variations in performance that arise out of variations in the level of equity that is private. We investigate the average impact of privatization by comparing privatized firms to firms that remain state-owned through 1991-1998 by estimating the following firm fixed effects specification:

$$
y_{i t}=\alpha+P R I V_{i t} \beta+X_{i t} \gamma+Y E A R_{t} \theta+\varepsilon_{i t},
$$

where $P R I V_{i t}$ measures the fraction of equity of firm $i$, lying between 0 and 100 , that is privately owned in period $t$. We assess the impact on profitability by examining both sales and accounting profits. Specifically the dependent variables for profitability are $(\log )$ sales and $(\log )$ profits. We also investigate the effect on efficiency with the (log) average product of labor and the returns to employment as dependent variables. Finally we examine if partial privatization has an impact on employment with (log) labor as the dependent variable. The $X_{i t}$ variables are firm specific factors including firm size measured by one-year lagged values of (log) gross fixed assets, and the one-year lagged share of government financing in total borrowing. Including the firms that remain state-owned as the control group allows us to estimate the average impact of private ownership, and control for contemporaneous macroeconomic shocks. This specification also allows for a firm-specific fixed effect, $\alpha_{i}$, which reflects fixed differences across firms that are constant but unobserved over time, time effects which are common to firms but vary over time given by the year dummies $Y E A R$, and a random unobserved component $\varepsilon_{i t}$.

Government loans are also used by Bartel and Harrison (2001) as an explanatory variable (they use the share of government loans in total investment) to capture the effects of a soft budget constraint on public sector firms. Soft budget constraints are expected to have a negative impact on firm performance if they are used by the government to pursue other objectives. They can also distort managerial incentives because they insulate public sector managers from the discipline of a bankruptcy threat. ${ }^{17}$ The results are presented in Table 4.

\footnotetext{
${ }^{17}$ However, Laffont and Tirole (1993) point out that even private regulated firms are
} 
It can be seen from Table 4 that the fraction of equity that is private in a given year has a positive and statistically significant (at the 1 per cent level) impact on all profitability and labor productivity measures. In column 1 of Table 4 increasing private equity by 10 percentage points would increase sales by 27 percentage points on average. In column 2 we find that the lagged share of government loans over total borrowing, which is a proxy for soft budget constraints, has a negative and slightly statistically significant impact on current sales. ${ }^{18}$

In columns 3 and 4 we investigate the impact on (log) accounting profits, and the results are similar to those reported for sales. ${ }^{19}$ A 10 percentage point decrease in government ownership would increase profits by 15 percentage points and this coefficient is also significant at the 1 per cent level. In column 4 soft budget constraints have a smaller but negative and statistically significant (at the 10 per cent level) impact on profits.

Examining the average impact of privatization on efficiency, columns 5 and 6 show that private ownership has a positive and statistically significant effect (at the 1 per cent level) on the average product of labor as measured by the $(\log )$ ratio of sales to employment. ${ }^{20}$ Size of capital, as measured by the log of lagged gross fixed assets, also has a significant and positive impact on the average product of labor, however the coefficient does not remain significant when we include the government loans variable. The lagged share of government loans in total borrowing has no impact on the average product of labor. In columns 7 and 8 we use returns to employment (the ratio of operating income to employment) as the dependent variable. This measure of efficiency has also been used by LaPorta and Lopez-di-Silanes (1999) among others. The coefficient of $P R I V$ is positive and statistically significant at the 1 per cent level. In contrast to its effect on sale revenues and profits, the lagged share of government loans in total borrowing has a positive and significant impact on returns to employment.

Investigating the average effect of private ownership on employment in columns 9 and 10 of Table 4, we find that the level of private ownership

bailed out by regulators, hence the problem with soft budget constraints is not exclusively restricted to public firms.

${ }^{18}$ On average 13 firms in each year do not report government loans received in the previous year. 4 firms do not report government loans in any years.

${ }^{19}$ The fewer number of observations is due to the fact that six firms do not report profits in 1997. We ran all the specifications in Tables 4 and 5 with the smallest balanced panel of 1506 firms. The coefficients retain their significance and sign and differ very slightly in magnitude. These results are available on request.

${ }^{20}$ There are fewer observations since we were unable to obtain employment data for some firms in some years. Only one firm is missing employment in all years. 
does not lead to a decline in employment, and is even slightly positive and significant when we do not control for the lagged share of government loans in total borrowing. This result is consistent with the conventional wisdom that partial privatization has not resulted in labor restructuring. Moreover, this also offers further evidence that the government's objectives have not undergone a significant change since there do not appear to be any layoffs of surplus workers following partial privatization. Finally, we report the F-test of joint significance for the firm fixed-effects and find that the fixed effects are jointly different from zero in all the specifications.

The evidence regarding the average impact of partial privatization on revenues, profitability, and operating efficiency suggests that managers of these firms undertake efficiency and profit-enhancing actions, possibly because public stock price information facilitates monitoring of manager performance. One could argue that without bankruptcy risks or a market for corporate control, managers need not respond to more high-powered incentives. However, the presence of a market for managerial skills could lead to restructuring efforts among managers whose performance is now being monitored more frequently or more accurately (Fama, 1980). Alternatively, the additional information on firm performance may also be used by the government and workers of the firm to monitor managers more effectively. As mentioned earlier, the alternative explanation that managers' incentives are not affected by better information, but instead by the possibility of losing their jobs after privatization, does not provide an unambiguous prediction since managers may also take actions to discourage potential buyers. It may also be the case that the increase in revenues and profits are a result of a reduction in corruption, rather than an increase in production. Due to increased monitoring of firm performance managers may stop illegally redirecting output to non-paying customers (Laporta and Lopez-di-Silanes, 1999, argue that this may also have been the case with Mexican firms).

It may be worthwhile to mention that we have also investigated the difference between pre and post privatization performance. In particular we include a dummy variable in the above estimations for the years preceding the first tranche in which a firm is sold. In contrast to other studies that find revenue and profitability measures increase prior to privatization (Dewenter and Malatesta, 2001) we find that sales and profitability are likely to be significantly lower in the prior years. Hence there is little evidence to suggest that firms manipulate their accounts prior to privatization. To save space we do not report these results.

That private ownership has an impact on firm performance at all is surprising since on average less than two percent of equity is private over 
this period in our sample. Even among the 36 privatized firms the average value of $P R I V$ is 16.32 per cent between 1991 and 1998. Moreover all these firms remained under government control over this period, leading us to conclude that the average impact of this variable captures the effect of increased monitoring on managers rather than restructuring brought about by a change in owner objectives.

\subsection{Evaluating the effect of increased competition}

We now explore another possible source of variation in firm performance by investigating whether partial privatization still has an impact when we control for changes in the competitive environment of firms. We estimate the previous specifications by introducing two dummy variables that capture the changing effect over time of increased competition. The first is a dummy variable that equals one if the firm is an industry which was originally reserved for the public sector and subsequently opened to the private sector, DEREST, which is interacted with a time trend. The second is a dummy variable that equals one if the firm is an industry where the government removed restrictions on foreign entry, $L I B T$, and it is also interacted with a time trend. An advantage of using these variables is that they measure potential entry due to deregulation rather than actual measures of market concentration and entry after deregulation, and hence do not suffer from endogeneity problems. The results are presented in Table 5 .

The coefficient of the fraction of private equity remains positive, of similar magnitude, and statistically significant at 1 per cent for sales, profitability, and the efficiency measures when we control for changes in competitive conditions. The lagged share of government loans in total borrowing continues to have a negative and statistically significant impact on sales and profits, and a positive impact on returns to labor. The impact of dereservation, as measured by the coefficient of DEREST, is positive and statistically significant for sales and profits. Dereservation has the additional effect of reducing employment in firms compared to firms in industries that were not restricted to government enterprises ${ }^{21}$. Freeing restrictions on private participation does not, however, have an impact on the average product of labor and the returns to employment, as seen in columns 4 and 5. In contrast to the effect of dereservation, liberalization of restrictions on foreign entry has a statistically significant negative impact on sales. The different effect of dereservation and liberalization on sales is interesting since

\footnotetext{
${ }^{21}$ We do not have firms in our data which belong to sectors that are still reserved such as arms and ammunition, atomic energy, and railways.
} 
both policies increase competition. The positive effect on firm sales in sectors previously reserved for state-owned firms may reflect the impact of less government intervention, or partnerships with private domestic and foreign firms. Although most of the firms in liberalized sectors were already competing with domestic companies before 1991, it has been argued that prior to the economic reforms, most industries, even those with domestic private sector firms, were not globally competitive because they enjoyed protection from imports and other favorable government policies. Hence at least in the short run the entry of foreign companies and foreign imports has adversely affected sales in firms in these sectors.

Relative to sectors that were never reserved for the government and those sectors that have not been opened to foreign companies, firms in both dereserved and liberalized sectors have lower employment on average, as seen in columns 6 of Table 5. Hence competitive pressures increase allocative efficiency by forcing firms to undertake some labor restructuring.

The results of Table 5 indicate that the effect of selling equity in a given year on firm performance cannot be attributed to changes in the competitive environment since $P R I V$ continues to have a statistically significant impact (at the 1 per cent level) on revenues, profits, and productivity. From the evidence it also appears that competition and privatization are complementary in their effect on firm performance, with partial sales increasing profitability and productive efficiency on average, while competition appears to increase allocative efficiency. It also appears that the effect on managers' incentives of dereservation policies has been positive, at least in terms of increasing sales and profits. However, contrary to Vickers and Yarrow (1991), the evidence suggests that competitive pressures alone would not fully address this inefficiency since competition policy does not have a broad impact on labor productivity.

\subsection{Addressing problems in estimation strategy}

The main advantage of a fixed effects estimation in the program evaluation literature is that it would control for the sort of selection bias that may arise if for example more shares are likely to be sold of better firms, where the unobservable characteristics do not change over time. However fixed effect estimations may result in inconsistent estimates if there is dynamic selection into privatization. For example, we would overestimate the impact of privatization if privatized firms experience a decline in performance prior to privatization which other firms do not, a phenomenon commonly referred to as "Ashenfelter's dip" (Ashenfelter, 1978). Like Bartel and Harrison 
(2001), we compare the pre-privatization performance of firms to that of firms that did not change ownership. Table 6 compares the change in sales, change in employment, and change in average product between $t$ and $t-1$ for firms privatized in year $t$ with firms that did not change ownership in that year. The results show that firms do not perform differently in terms of sales, employment or average product compared to the control group prior to privatization.

Dynamic selection bias may also arise for example if the government is likely to select firms for privatization that have better management, or firms that are likely to adapt better to the new liberalization policies, but these factors are unobservable to the researcher and not fixed over time. It would be impossible to control for all such factors particularly if they are unobserved and evolve over time. However, if firms that are selected for privatization share similar characteristics that are not captured by pre-privatization measures and materialize over time, then comparing firms privatized in a given year to a control group of firms that have also been selected for privatization, but are privatized in other years, may allow us to control for this type of selection bias. Frydman et al. (1999) use this approach by comparing firms that were privatized later to firms that were privatized earlier. Since privatization is distributed over several years in our data, in any given year we also observe firms privatized in later years that potentially share similar unobservable time variant characteristics. In the control group we also include all the firms that have been partially and fully privatized between 1998 (the last year of our sample) and 2001, including 5 firms for which sales negotiations were completed in late 2001. We estimate the specifications in Table 5 and report the results in Table 7 . The coefficient of the $P R I V$ variable remains similar to Tables 4 and 5 in magnitude and statistical significance for almost all the specifications other than employment. It is interesting to note that the lagged share of government loans in total borrowing now has a significant and positive impact on employment in the smaller sample, consistent with Shleifer and Vishny's (1994) view that the government may use loans to induce firms to retain surplus labor.

The institutional background of the disinvestment process in India leads us to believe that dynamic selection is not a major problem. The debate in policy circles and in the media has focused on the absence of a privatization plan on which firms to sell, how much to sell, and when to sell. An editorial in the prominent Indian business newspaper The Economic Times (May, 2001) reflecting general perception about the process thus far commented: "The disinvestment programme of the government is completely incoherent and lacks transparency and conviction." 
Griliches and Hausman (1986) note that errors in variables can be heightened by fixed effects. We do not think measurement error is a problem since the privatization variable is quite statistically significant, while measurement error tends to bias coefficients towards zero.

We also conduct some other robustness checks. In particular we reestimate excluding oil and gas companies which are arguably the more profitable companies that were partially privatized. We do not find any evidence that these results are being driven by particular sectors. For example for the specification in column 1 of Table 4 we find that the coefficient (standard error) of $P R I V$ is .029(.004) and significant at the 1 per cent level, and it retains its sign, magnitude and significance for the other specifications as well. The results are similar when we include the competition variables.

We also estimate these specifications by excluding firms owned by regional governments. Once again we find the results to be substantially similar with all the coefficients retaining their sign and significance. There is no evidence that the results of Tables 4 and 5 are affected by the inclusion of these firms.

\section{Conclusion}

We find that partial privatization in the form of diffuse minority sales of shares has a positive impact on firm profitability and efficiency without being accompanied by a decline in employment. Since there is no transfer of control it is difficult to argue that the observed improvement in performance occurs because of a shift in owners' objectives to profit maximization. Instead, improvements in firm performance are more likely to have occurred because of a change in manager incentives as a result of more information on and monitoring of managers after partial privatization. Partial privatization can also increase the incentives of stock market analysts to follow the performance of a government owned firm because of the possibility that more shares will be sold in the future.

Policies that increase competition also have an impact on firm performance. We find that removal of entry barriers in sectors that were restricted to government-owned firms has a favorable impact on sales, but liberalization of restrictions on foreign ownership appears, at least in the short run, to reduce sales. Moreover, competitive pressures appear to force managers to make layoffs. Our results suggest that both partial privatization and competition affect the performance of these public sector firms.

One useful extension of this analysis would be to include additional pol- 
icy variables measuring changes in market conditions such as trade policy changes. It would also be useful to include private sector firms in this analysis and compare government-owned firms to their private sector counterparts. 


\section{References}

[1] Ashenfelter, O. (1978). "Estimating the Effect of Training on Earnings." Review of Economics and Statistics, Vol. 60 (1), pp. 47-57.

[2] Bartel, A. and A. Harrison (2001). "Ownership versus Environment: Disentangling the Sources of Public Sector Inefficiency." Manuscript.

[3] Bertrand, M., P. Mehta, and S. Mullainathan (2001). "Ferreting out Tunneling: An Application to Indian Business Groups." forthcoming in the Quarterly Journal of Economics.

[4] Coase, R. (1960). "The Problem of Social Cost." Journal of Law and Economics, Vol. 1, pp. 1-44.

[5] Department of Disinvestment (2001). "Presentation on Disinvestment." Government of India, pp. 1-75.

[6] Department of Public Enterprises (2001). "Annual Report 1999-2000." Government of India, Annexure I.

[7] Dewenter, K. and P.Malatesta (2001). "State-Owned and PrivatelyOwned Firms: An Empirical Analysis of Profitability, Leverage, and Labor Intensity." American Economic Review, Vol. 91, pp. 320-34.

[8] Fama, E.F. (1980). "Agency Problems and the Theory of the Firm." Journal of Political Economy, Vol 88 (2), pp. 288-307.

[9] Frydman, R., C. Gray, M. Hessel, and A. Rapaczynski (1999). "When Does Privatization Work? The Impact of Private Ownership on Corporate Performance in Transition Economies." Quarterly Journal of Economics, Vol. 114 (4), pp. 1153-91.

[10] Goyal, S.K. (1999). "Privatization in India." In Privatization in South Asia: Minimizing Negative Social Effects through Restructuring, Report on the Subregional Meeting on Privatization in South Asia, Chap. 3, Bangkok: International Labour Organization.

[11] Griliches, Z. and J. Hausman (1986). "Errors in Variables in Panel Data." Journal of Econometrics, Vol (31), pp. 93-118.

[12] Grossman, S.J. and O. D. Hart (1986). "The Costs and Benefits of Ownership: A Theory of Vertical and Lateral Integration." Journal of Political Economy, Vol. 94 (4), pp. 691-719. 
[13] Hart, O.D., (1983). "The Market Mechanism as an Incentive Scheme." Bell Journal of Economics, Vol. 14(2), pp. 366-82.

[14] Holmstrom, B. and J. Tirole (1993). "Market Liquidity and Performance Monitoring." Journal of Political Economy, Vol. 101(4), pp. 678-709.

[15] Jones, S., W. Megginson, R. Nash, and J. Netter (1999). "Share Issue Privatizations as Financial Means to Political Ends." Journal of Financial Economics, Vol. 53, pp. 217-53.

[16] Laffont, J-J. and J. Tirole (1993). A Theory of Incentives in Procurement and Regulation. Cambridge: MIT Press.

[17] LaPorta, R. and F. Lopez-di-Silanes (1999). "Benefits of Privatization - Evidence from Mexico." Quarterly Journal of Economics, Vol. 114 (4), pp. 1193-242.

[18] Megginson, W.L., R. Nash, and M. van Randenborgh (1994). "The Financial and Operating Performance of Newly Privatized Firms: An International Empirical Analysis." Journal of Finance, Vol 49, pp. 40352 .

[19] Megginson, W.L. and J.M. Netter (June 2001). "From State to Market: A Survey of Empirical Studies on Privatization." Journal of Economic Literature, Vol. 39 (2), pp. 321-89.

[20] Sappington, D.E. and J. Stiglitz (1987). "Privatization, Information, and Incentives." Journal of Policy Analysis and Management, Vol 6, pp. $567-82$.

[21] Shleifer, A. and R. Vishny. "Politicians and Firms." Quarterly Journal of Economics, 1994, Vol. 109, pp. 995-1025.

[22] Shleifer, A. and R. Vishny (1997). "A Survey of Corporate Governance." Journal of Finance, Vol 52 (2), 737-783.

[23] Vickers, J. and G. Yarrow (1989). Privatization: An Economic Analysis. Cambridge: MIT Press.

[24] Vickers, J. and G. Yarrow (1991). "Economic Perspectives on Privatization." Journal of Economic Perspectives, Volume 5, pp. 111-32.

[25] Williamson, O. (1985). The Economic Institutions of Capitalism. New York: Free Press. 
Variable

SALES

PROFITS

LABOR

ASSETS
Log of annual revenue generated by an enterprise from its main business activity measured by charges to customers for goods supplied and services rendered.

Excludes income from activities not related to main business, such as dividends, interest, and rents in the case of industrial firms, as well as non-recurring income.

Log of the annual excess of income over all expenditures except tax, depreciation, interest payments, rent, and extra ordinary expenditures. Does not include extraordinary income and income from sources not related to main business activity.

Log of the total number of employees in a year including managerial staff.

Log of annual gross fixed assets which include movable and immovable assets as well as assets which are in the process of being installed

AVERAGE PRODUCT ' Log of the ratio of sales over total employment OF LABOR

GOVERNMENT

LOANS AND

SUBSIDIES

TOTAL BORROWING

GOVT LOAN/

TOT BORR

RETURNS TO

LABOR

DEREST

LIBT

PRIV
Log of the sum of annual loans received from the central and state governments and government owned development institutions, and subsidies given by the government.

Log of total borrowings including loans from banks, institutions, debentures, other companies, tax deferrals, foreign and other borrowings.

Ratio of government loans to total borrowings

Ratio of operating income to total employment. Operating income is measured as sales minus the total cost of raw materials, wages and energy costs.

Dummy variable that is equal to one if the firm is in an industry that was reserved for government-owned firms until 1991, interacted with a time trend

Dummy variable that is equal to one if the firm is in an industry that removed restrictions on foreign ownership after 1991, interacted with a time trend

Variable that lies between 0 and 100 measuring the fraction of equity that is private in a firm in a given year

Year dummies excluding 1991 
TABLE 1

PRIVATIZATION BY YEAR

\begin{tabular}{|c|c|c|c|c|}
\hline YEAR & $\begin{array}{l}\text { NUMBER OF } \\
\text { FIRMS SOLD }\end{array}$ & $\begin{array}{c}\text { AVERAGE } \\
\text { FRACTION OF } \\
\text { EQUITY SOLD } \\
\text { (standard errors in } \\
\text { parentheses) } \\
\end{array}$ & $\begin{array}{l}\text { MAXIMUM } \\
\text { FRACTION OF } \\
\text { EQUITY SOLD }\end{array}$ & $\begin{array}{l}\text { MINIMUM } \\
\text { FRACTION OF } \\
\text { EQUITY SOLD }\end{array}$ \\
\hline 1991 & 3 & $\begin{array}{c}17.24 \\
(19.53)\end{array}$ & 38.84 & .12 \\
\hline 1992 & 26 & $\begin{array}{l}11.77 \\
(7.60)\end{array}$ & 20.1 & 1.23 \\
\hline 1993 & 16 & $\begin{array}{c}3.65 \\
(3.66)\end{array}$ & 10.08 & .06 \\
\hline 1994 & 9 & $\begin{array}{c}3.24 \\
(6.08)\end{array}$ & 17.6 & .01 \\
\hline 1995 & 18 & $\begin{array}{c}7.06 \\
(7.69)\end{array}$ & 23.1 & .01 \\
\hline 1996 & 9 & $\begin{array}{c}2.24 \\
(2.86)\end{array}$ & 9.25 & .03 \\
\hline 1997 & 3 & $\begin{array}{l}15.90 \\
(9.06)\end{array}$ & 26 & 8.5 \\
\hline 1998 & 1 & 17 & 17 & 17 \\
\hline \multicolumn{5}{|c|}{$\begin{array}{l}\text { DISTRIBUTION OF DERESERVED FIRMS AND LIBERALIZED FIRMS (NUMBER OF FIRM } \\
\text { YEARS) }\end{array}$} \\
\hline $\begin{array}{l}\text { Liberalized } \\
\text { Firms }\end{array}$ & $\begin{array}{l}\text { Dereserved Firms } \\
160\end{array}$ & $\begin{array}{l}\text { Non dereserved Firms } \\
278\end{array}$ & & \\
\hline $\begin{array}{l}\text { Non- } \\
\text { liberalized } \\
\text { Firms } \\
\end{array}$ & 475 & 1045 & & \\
\hline
\end{tabular}

Notes: 36 central government firms partially privatized between 1991 and 1998 of which some are sold in several tranches. 2 state government firms also included. Equity sold lies between 0 and 100 . 
TABLE 2

SUMMARY STATISTICS BY OWNERSHIP CATEGORY 1991-1998

\begin{tabular}{|c|c|c|c|}
\hline & $\begin{array}{c}\text { ALL } \\
\text { FIRMS } \\
\end{array}$ & $\begin{array}{l}\text { PARTIALLY PRIVATIZED } \\
\text { FIRMS } \\
\end{array}$ & $\begin{array}{c}\text { STATE-OWNED } \\
\text { FIRMS } \\
\end{array}$ \\
\hline SALES & $\begin{array}{c}828.32 \\
(3316.56) \\
N=1958\end{array}$ & $\begin{array}{c}3907.14 \\
(8132.71) \\
N=234\end{array}$ & $\begin{array}{c}410.42 \\
(1444.68) \\
N=1724\end{array}$ \\
\hline PROFITS & $\begin{array}{c}391.43 \\
(501.88) \\
N=1952\end{array}$ & $\begin{array}{c}861.51 \\
(1093.99) \\
N=233\end{array}$ & $\begin{array}{c}327.71 \\
(300.66) \\
N=1719\end{array}$ \\
\hline EMPLOYEES & $\begin{array}{c}9612.93 \\
(23637.57) \\
N=1507\end{array}$ & $\begin{array}{c}19775.88 \\
(33825.63) \\
N=212\end{array}$ & $\begin{array}{c}7949.18 \\
(21071.61) \\
N=1295\end{array}$ \\
\hline ASSETS & $\begin{array}{c}745.54 \\
(2892.85) \\
N=1958\end{array}$ & $\begin{array}{c}2650.03 \\
(6135.19) \\
N=234\end{array}$ & $\begin{array}{c}487.04 \\
(1963.56) \\
N=1724\end{array}$ \\
\hline $\begin{array}{l}\text { AVERAGE PRODUCT OF } \\
\text { LABOR }\end{array}$ & $\begin{array}{c}.134 \\
(.302) \\
\mathrm{N}=1507\end{array}$ & $\begin{array}{c}.328 \\
(.490) \\
\mathrm{N}=212\end{array}$ & $\begin{array}{c}.082 \\
(.162) \\
\mathrm{N}=1295\end{array}$ \\
\hline RETURNS TO LABOR & $\begin{array}{c}.046 \\
(.144) \\
\mathrm{N}=1507\end{array}$ & $\begin{array}{c}.143 \\
(.289) \\
\mathrm{N}=212\end{array}$ & $\begin{array}{c}.030 \\
(.094) \\
\mathrm{N}=1295\end{array}$ \\
\hline $\begin{array}{l}\text { GOVT LOAN } \\
\text { / TOT BORR }\end{array}$ & $\begin{array}{c}.297 \\
(.359) \\
\mathrm{N}=1958\end{array}$ & $\begin{array}{c}.141 \\
(.223) \\
\mathrm{N}=234\end{array}$ & $\begin{array}{c}.318 \\
(.369) \\
\mathrm{N}=1724\end{array}$ \\
\hline
\end{tabular}

Notes: Variables are not measured in logs. Units equal millions of US\$. Labor measured in actual number of workers. N refers to firm years for each variable and ownership category. Share of government loans over total borrowing is lagged one year as in regressions. Sample size is same as in Tables 3, 4 and 5. 
TABLE 3

COMPARING PERFORMANCE BEFORE AND AFTER PRIVATIZATION

(1990-1998)

\begin{tabular}{|c|c|c|c|}
\hline VARIABLE & $\begin{array}{l}\text { MEAN BEFORE } \\
\text { PRIVATIZATION }\end{array}$ & $\begin{array}{l}\text { MEAN AFTER } \\
\text { PRIVATIZATION }\end{array}$ & $\begin{array}{l}\text { POST-PRE } \\
\text { t-statistic of difference } \\
\text { in means }\end{array}$ \\
\hline \multicolumn{4}{|c|}{ REVENUES } \\
\hline SALES & $\begin{array}{l}6.293 \\
(.193)\end{array}$ & $\begin{array}{l}6.883 \\
(.120)\end{array}$ & $2.173^{* *}$ \\
\hline PROFITS & $\begin{array}{l}6.131 \\
(.080)\end{array}$ & $\begin{array}{l}6.357 \\
(.050)\end{array}$ & $2.007^{* *}$ \\
\hline \multicolumn{4}{|c|}{ EFFICIENCY } \\
\hline $\begin{array}{l}\text { AVERAGE PRODUCT } \\
\text { OF LABOR }\end{array}$ & $\begin{array}{l}.206 \\
(.042)\end{array}$ & $\begin{array}{l}.229 \\
(.019)\end{array}$ & .500 \\
\hline \multicolumn{4}{|c|}{ ASSETS } \\
\hline $\begin{array}{l}\text { GROSS FIXED } \\
\text { ASSETS }\end{array}$ & $\begin{array}{l}6.250 \\
(.231)\end{array}$ & $\begin{array}{l}6.161 \\
(.157)\end{array}$ & -.255 \\
\hline \multicolumn{4}{|c|}{ FINANCING } \\
\hline $\begin{array}{l}\text { GOVERNMENT } \\
\text { LOANS AND } \\
\text { SUBSIDIES }\end{array}$ & $\begin{array}{l}2.771 \\
(.317)\end{array}$ & $\begin{array}{l}2.898 \\
(.149)\end{array}$ & .367 \\
\hline TOTAL BORROWING & $\begin{array}{l}4.775 \\
(.311)\end{array}$ & $\begin{array}{l}5.351 \\
(.154)\end{array}$ & $1.630^{*}$ \\
\hline $\begin{array}{l}\text { GOVT LOAN } \\
\text { / TOT BORR }\end{array}$ & $\begin{array}{l}.194 \\
(.035)\end{array}$ & $\begin{array}{l}.136 \\
(.014)\end{array}$ & $-1.700^{*}$ \\
\hline
\end{tabular}

Notes: All variables measured in logs, standard errors of means in parentheses. Mean values computed for firm performance before and after the first tranche of privatization for each firm.

* Significant at the 10 per cent level

** Significant at the 5 per cent level

*** Significant at the 1 per cent level 
TABLE 4

THE IMPACT OF PRIVATE OWNERSHIP ON FIRM PERFORMANCE

COMPARING PRIVATIZED FIRMS TO STATE-OWNED FIRMS (1990-1998)

(Fixed Effects Estimates)

\begin{tabular}{|c|c|c|c|c|c|c|c|c|c|c|}
\hline & \multicolumn{2}{|c|}{ SALES $_{\mathrm{t}}$} & \multicolumn{2}{|c|}{ PROFIT $_{t}$} & \multicolumn{2}{|c|}{$\begin{array}{l}\text { AVERAGE } \\
\text { PRODUCT }_{t}\end{array}$} & \multicolumn{2}{|c|}{$\begin{array}{l}\text { RETURNS TO } \\
\text { LABOR }_{\text {t }}\end{array}$} & \multicolumn{2}{|c|}{$\mathrm{LABOR}_{\mathrm{t}}$} \\
\hline $\operatorname{PRIV}_{i, t}$ & $\begin{array}{l}.027^{* * * *} \\
(.004)\end{array}$ & $\begin{array}{l}.023^{* * * *} \\
(.004)\end{array}$ & $\begin{array}{l}.015^{* * * *} \\
(.002)\end{array}$ & $\begin{array}{l}.014^{* * * *} \\
(.003)\end{array}$ & $\begin{array}{l}.006^{* * * *} \\
(.001)\end{array}$ & $\begin{array}{l}.005^{* * * *} \\
(.001)\end{array}$ & $\begin{array}{l}.008^{* * * *} \\
(.001)\end{array}$ & $\begin{array}{l}.006^{* * * *} \\
(.001)\end{array}$ & $\begin{array}{l}.004^{*} \\
(.002)\end{array}$ & $\begin{array}{l}.002 \\
(.002)\end{array}$ \\
\hline $\begin{array}{l}\text { GOVT LOAN } \\
\text { /TOT BORR }_{\mathrm{i}, \mathrm{t}-1}\end{array}$ & - & $\begin{array}{l}-.119^{*} \\
(.067)\end{array}$ & - & $\begin{array}{l}-.058^{*} \\
(.034)\end{array}$ & - & $\begin{array}{l}.008 \\
(.010)\end{array}$ & - & $\begin{array}{l}.023^{* * *} \\
(.010)\end{array}$ & - & $\begin{array}{l}.036 \\
(.042)\end{array}$ \\
\hline ASSETS $_{\mathrm{i}, \mathrm{t}-1}$ & $\begin{array}{l}.028^{* * *} \\
(.009)\end{array}$ & $\begin{array}{l}.016 \\
(.011)\end{array}$ & $\begin{array}{l}-.005 \\
(.005)\end{array}$ & $\begin{array}{l}-.004 \\
(.006)\end{array}$ & $\begin{array}{l}.003^{* *} \\
(.001)\end{array}$ & $\begin{array}{c}.002 \\
(.002)\end{array}$ & $\begin{array}{l}.004^{* *} \\
(.002)\end{array}$ & $\begin{array}{l}.003^{* *} \\
(.002)\end{array}$ & $\begin{array}{l}.007 \\
(.006)\end{array}$ & $\begin{array}{l}.001 \\
(.007)\end{array}$ \\
\hline $\begin{array}{l}\text { YEAR } \\
\text { DUMMIES }\end{array}$ & Yes & Yes & Yes & Yes & Yes & Yes & Yes & Yes & Yes & Yes \\
\hline $\begin{array}{l}\text { Number of } \\
\text { Firm-year } \\
\text { Observations }\end{array}$ & 2063 & 1958 & 2057 & 1952 & 1582 & 1506 & 1582 & 1506 & 1602 & 1522 \\
\hline $\mathrm{R}^{2}$ & .0508 & .0414 & .0494 & .0478 & .1244 & .1030 & .1558 & .1313 & .0050 & .0041 \\
\hline $\operatorname{Pr}>\mathrm{F}(\mathrm{k}, \mathrm{NT}-\mathrm{k})^{\mathrm{a}}$ & $.000^{* * * *}$ & $.000^{* * * *}$ & $.000^{* * *}$ & $.000^{* * * *}$ & $.000^{* * * *}$ & $.000^{* * * *}$ & $.000^{* * * *}$ & $.000^{* * *}$ & .552 & .810 \\
\hline $\operatorname{Pr}>F^{b}$ & $.000^{* * * *}$ & $.000^{* * *}$ & $.000^{* * *}$ & $.000^{* * * *}$ & $.000^{* * * *}$ & $.000^{* * *}$ & $.000^{* * *}$ & $.000^{* * * *}$ & $.000^{* * * *}$ & $.000^{* * *}$ \\
\hline
\end{tabular}

Notes: Specifications control for firm level fixed effects (within regressions). Standard errors are in parentheses. All RHS variables except PRIV are lagged one year. All performance variables are measured in logarithms except returns to labor and the share of government loans in total borrowing.

* Significant at the 10 per cent level

** Significant at the 5 per cent level

*** Significant at the 1 per cent level

a: Joint significance test for all coefficients

b: Joint significance test for firm fixed effects, F statistic distributed with (N, NT-N-k-1) degrees of freedom, where $\mathrm{N}$ equals number of firms, $\mathrm{T}$ equals number of years, and $\mathrm{k}$ is the number of RHS variables. 
TABLE 5

THE IMPACT OF PRIVATE OWNERSHIP AND COMPETITION

ON FIRM PERFORMANCE

COMPARING PRIVATIZED FIRMS TO STATE-OWNED FIRMS (1990-1998)

(Fixed Effects Estimates)

\begin{tabular}{|c|c|c|c|c|c|}
\hline & SALES $_{\mathrm{t}}$ & PROFIT $_{t}$ & $\begin{array}{l}\text { AVERAGE } \\
\text { PRODUCT }_{\mathrm{t}}\end{array}$ & $\begin{array}{l}\text { RETURNS TO } \\
\text { LABOR }_{\mathrm{t}}\end{array}$ & $\mathrm{LABOR}_{\mathrm{t}}$ \\
\hline $\mathrm{PRIV}_{\mathrm{i}, \mathrm{t}}$ & $\begin{array}{l}.021^{* * *} \\
(.004)\end{array}$ & $\begin{array}{l}.014^{* * *} \\
(.003)\end{array}$ & $\begin{array}{l}.005^{* * * *} \\
(.001)\end{array}$ & $\begin{array}{l}.006^{* * *} \\
(.001)\end{array}$ & $\begin{array}{l}.004^{*} \\
(.002)\end{array}$ \\
\hline DEREST $_{i, t}$ & $\begin{array}{l}.048^{* * *} \\
(.012)\end{array}$ & $\begin{array}{l}.016^{* * *} \\
(.006)\end{array}$ & $\begin{array}{c}.003 \\
(.002)\end{array}$ & $\begin{array}{l}.001 \\
(.002)\end{array}$ & $\begin{array}{l}-.022^{* * * *} \\
(.007)\end{array}$ \\
\hline $\mathrm{LIBT}_{\mathrm{i}, \mathrm{t}}$ & $\begin{array}{l}-.034^{* * * *} \\
(.010)\end{array}$ & $\begin{array}{l}.003 \\
(.005)\end{array}$ & $\begin{array}{l}-.001 \\
(.001)\end{array}$ & $\begin{array}{l}-.001 \\
(.001)\end{array}$ & $\begin{array}{l}-.025^{* * * *} \\
(.006)\end{array}$ \\
\hline $\begin{array}{l}\text { GOVT LOAN } \\
\text { / TOT BORR } \text { BOT,-1-1 }^{2}\end{array}$ & $\begin{array}{c}-.114^{*} \\
(.066)\end{array}$ & $\begin{array}{l}-.057^{*} \\
(.034)\end{array}$ & $\begin{array}{l}.009 \\
(.010)\end{array}$ & $\begin{array}{l}.023^{* * *} \\
(.009)\end{array}$ & $\begin{array}{l}.031 \\
(.042)\end{array}$ \\
\hline $\operatorname{ASSETS}_{\mathrm{i}, \mathrm{t}-1}$ & $\begin{array}{l}.019^{*} \\
(.011)\end{array}$ & $\begin{array}{l}-.004 \\
(.006)\end{array}$ & $\begin{array}{l}.002 \\
(.002)\end{array}$ & $\begin{array}{l}.003^{* *} \\
(.001)\end{array}$ & $\begin{array}{l}.000 \\
(.007)\end{array}$ \\
\hline $\begin{array}{l}\text { YEAR } \\
\text { DUMMIES }\end{array}$ & Yes & Yes & Yes & Yes & Yes \\
\hline $\begin{array}{l}\text { Number of } \\
\text { Firm-year } \\
\text { Observations }\end{array}$ & 1958 & 1952 & 1506 & 1506 & 1522 \\
\hline $\mathrm{R}^{2}$ & .0542 & .0525 & .1048 & .1318 & .0284 \\
\hline $\operatorname{Pr}>F(k, N T-k)^{a}$ & $.000^{* * * *}$ & $.000^{* * *}$ & $.000^{* * * *}$ & $.000^{* * *}$ & $.000^{* * * *}$ \\
\hline $\operatorname{Pr}>F^{b}$ & $.000^{* * * *}$ & $.000^{* * *}$ & $.000^{* * * *}$ & $.000^{* * * *}$ & $.000^{* * * *}$ \\
\hline
\end{tabular}

Notes: Specifications control for firm level fixed effects (within regressions). Standard errors are in parentheses. All RHS variables except PRIV are lagged one year. All performance variables are measured in logarithms except returns to labor and the share of government loans in total borrowing and the dummy variables DEREST and LIBT.

* Significant at the 10 per cent level

** Significant at the 5 per cent level

*** Significant at the 1 per cent level

a: Joint significance test for all coefficients

b: Joint significance test for firm fixed effects, F statistic distributed with (N, NT-N-k-1) degrees of freedom, where $\mathrm{N}$ equals number of firms, T equals number of years, and $\mathrm{k}$ is the number of RHS variables. 
TABLE 6

MEAN CHANGE IN PERFORMANCE BEFORE PRIVATIZATION (1990-1998)

\begin{tabular}{lccc}
\hline & $\begin{array}{c}\text { PRIVATIZED } \\
\text { FIRMS }\end{array}$ & $\begin{array}{c}\text { UNPRIVATIZED } \\
\text { FIRMS }\end{array}$ & $\begin{array}{c}\text { PRIVATIZED- } \\
\text { UNPRIVATIZED } \\
\text { t-statistic of difference in } \\
\text { means }\end{array}$ \\
\hline \hline SALES $_{\mathrm{t}}-$ SALES $_{\mathrm{t}-1}$ & .115 & .059 & 1.07 \\
LABOR $_{\mathrm{t}}-$ LABOR $_{\mathrm{t}-1}$ & $(.020)$ & $(.011)$ & \\
& -.003 & -.028 & .604 \\
AVERAGE PRODUCT $_{\mathrm{t}}-$ & $(.004)$ & $(.010)$ & 1.07 \\
AVERAGE PRODUCT $_{\mathrm{t}-1}$ & .018 & .009 & \\
\hline
\end{tabular}

Notes: Standard errors of means in parentheses for all growth measures. Performance measures are log differences. Year $t$ is year of privatization. 
TABLE 7

THE IMPACT OF PRIVATE OWNERSHIP AND COMPETITION

ON FIRM PERFORMANCE

COMPARING PRIVATIZED FIRMS TO FIRMS SELECTED FOR PRIVATIZATION

(1990-1998)

(Fixed Effects Estimates)

\begin{tabular}{|c|c|c|c|c|c|c|c|c|c|c|}
\hline & \multicolumn{2}{|c|}{ SALES $_{t}$} & \multicolumn{2}{|c|}{ PROFIT $_{t}$} & \multicolumn{2}{|c|}{$\begin{array}{l}\text { AVERAGE } \\
\text { PRODUCT }_{t} \\
\end{array}$} & \multicolumn{2}{|c|}{$\begin{array}{l}\text { RETURNS TO } \\
\text { LABOR }_{\mathrm{t}}\end{array}$} & \multicolumn{2}{|c|}{$\mathrm{LABOR}_{t}$} \\
\hline PRIV $_{i, t}$ & $\begin{array}{l}.020^{* * *} \\
(.003)\end{array}$ & $\begin{array}{l}.019^{* * * *} \\
(.003)\end{array}$ & $\begin{array}{l}.014^{* * *} \\
(.002)\end{array}$ & $\begin{array}{l}.014^{* * * *} \\
(.002)\end{array}$ & $\begin{array}{l}.005^{* * * *} \\
(.001)\end{array}$ & $\begin{array}{l}.005^{* * * *} \\
(.001)\end{array}$ & $\begin{array}{l}.007^{* * * *} \\
(.001)\end{array}$ & $\begin{array}{l}.007^{* * * *} \\
(.001)\end{array}$ & $\begin{array}{l}.002^{* * * *} \\
(.001)\end{array}$ & $\begin{array}{l}.004^{*} \\
(.001\end{array}$ \\
\hline $\begin{array}{l}\text { GOVT LOAN } \\
\text { /TOT BORR }_{\mathrm{i}, \mathrm{t}-1}\end{array}$ & $\begin{array}{c}-.433^{* * * *} \\
(.139)\end{array}$ & $\begin{array}{c}-.388^{* * * *} \\
(.144)\end{array}$ & $\begin{array}{l}.027 \\
(.082)\end{array}$ & $\begin{array}{l}.010 \\
(.085)\end{array}$ & $\begin{array}{l}.022 \\
(.034)\end{array}$ & $\begin{array}{l}.016 \\
(.035)\end{array}$ & $\begin{array}{l}.075^{*} \\
(.044)\end{array}$ & $\begin{array}{l}.076^{*} \\
(.045)\end{array}$ & $\begin{array}{l}.086^{* * *} \\
(.033)\end{array}$ & $\begin{array}{l}.036 \\
(.031)\end{array}$ \\
\hline DEREST & -- & $\begin{array}{l}.025 \\
(.018)\end{array}$ & -- & $\begin{array}{l}-.008 \\
(.011)\end{array}$ & -- & $\begin{array}{l}-.004 \\
(.005)\end{array}$ & -- & $\begin{array}{l}-.0002 \\
(.006)\end{array}$ & -- & $\begin{array}{l}-.029^{* * * *} \\
(.004)\end{array}$ \\
\hline LIBT & -- & $\begin{array}{l}.005 \\
(.019)\end{array}$ & -- & $\begin{array}{c}.013 \\
(.011)\end{array}$ & -- & $\begin{array}{l}-.007 \\
(.005)\end{array}$ & -- & $\begin{array}{l}-.010^{*} \\
(.006)\end{array}$ & -- & $\begin{array}{l}-.005 \\
(.004)\end{array}$ \\
\hline ASSETS $_{i,-1-1}$ & $\begin{array}{l}-.00003 \\
(.020)\end{array}$ & $\begin{array}{l}.002 \\
(.020)\end{array}$ & $\begin{array}{l}.010 \\
(.012)\end{array}$ & $\begin{array}{l}.007 \\
(.011)\end{array}$ & $\begin{array}{l}.008^{*} \\
(.005)\end{array}$ & $\begin{array}{l}.008^{*} \\
(.005)\end{array}$ & $\begin{array}{l}.011^{*} \\
(.006)\end{array}$ & $\begin{array}{l}.012^{*} \\
(.006)\end{array}$ & $\begin{array}{l}.002 \\
(.005)\end{array}$ & $\begin{array}{l}.001 \\
(.004)\end{array}$ \\
\hline $\begin{array}{l}\text { YEAR } \\
\text { DUMMIES }\end{array}$ & Yes & Yes & Yes & Yes & Yes & Yes & Yes & Yes & Yes & Yes \\
\hline $\begin{array}{l}\text { Number of } \\
\text { Firm-year } \\
\text { Observations }\end{array}$ & 325 & 325 & 323 & 323 & 290 & 290 & 290 & 290 & 292 & 292 \\
\hline $\mathrm{R}^{2}$ & .3353 & .3401 & .2947. & .2950 & .2839 & .2928 & .2306 & .2395 & .0815 & . 2586 \\
\hline $\operatorname{Pr}>\mathrm{F}(\mathrm{k}, \mathrm{NT}-\mathrm{k})^{\mathrm{a}}$ & $.000^{* * * *}$ & $.000^{* * * *}$ & $.000^{* * * *}$ & $.000^{* * *}$ & $.000^{* * *}$ & $.000^{* * * *}$ & $.000^{* * * *}$ & $.000^{* * * *}$ & $.013^{* * *}$ & $.000^{* *}$ \\
\hline $\operatorname{Pr}>F^{b}$ & $.000^{* * * *}$ & $.000^{* * *}$ & $.000^{* * *}$ & $.000^{* * *}$ & $.000^{* * * *}$ & $.000^{* * * *}$ & $.000^{* * * *}$ & $.000^{* * * *}$ & $.000^{* * *}$ & $.000^{* * *}$ \\
\hline
\end{tabular}

Notes: Specifications control for firm level fixed effects (within regressions). Standard errors are in parentheses. All RHS variables except PRIV are lagged one year. All performance variables are measured in logarithms except returns to labor and the share of government loans in total borrowing and the dummy variables DEREST and LIBT. See notes to Table 5. 


\section{DAVIDSON INSTITUTE WORKING PAPER SERIES - Most Recent Papers}

The entire Working Paper Series may be downloaded free of charge at: www.wdi.bus.umich.edu

CURRENT AS OF $1 / 18 / 02$

\begin{tabular}{|c|c|c|}
\hline Publication & Authors & Date \\
\hline $\begin{array}{l}\text { No. 426: Partial Privatization and Firm Performance: Evidence from } \\
\text { India }\end{array}$ & Nandini Gupta & Dec. 2001 \\
\hline $\begin{array}{l}\text { No. 425: Direct Foreign Investments and Productivity Growth in } \\
\text { Hungarian Firms, 1992-1999 }\end{array}$ & Jérôme Sgard & Nov. 2001 \\
\hline $\begin{array}{l}\text { No. 424: Banking Passivity and Regulatory Failure in Emerging } \\
\text { Markets: Theory and Evidence from the Czech republic. }\end{array}$ & Jan Hanousek and Gerard Roland & July 2001 \\
\hline $\begin{array}{l}\text { No. 423: Conceptions of the Corporation and the Prospects of } \\
\text { Sustainable Peace }\end{array}$ & Jeffrey Nesteruk & Dec. 2001 \\
\hline No. 422: The Role of the Corporation in Fostering Sustainable Peace & Timothy Fort and Cindy Schipani & Nov. 2001 \\
\hline No. 421: Wage Arrears and the Distribution of Earnings in Russia & $\begin{array}{l}\text { Hartmut Lehmann and Jonathan } \\
\text { Wadsworth }\end{array}$ & Dec. 2001 \\
\hline $\begin{array}{l}\text { No. 420: Transferring Collective Knowledge: Collective and } \\
\text { Fragmented Teaching and Learning in the Chinese Auto Industry }\end{array}$ & $\begin{array}{l}\text { Jane Zhou, Jaideep Anand, and } \\
\text { Will Mitchell }\end{array}$ & Dec. 2001 \\
\hline $\begin{array}{l}\text { No. 419: Liberalization, Corporate Governance, and the Performance of } \\
\text { Newly Privatized Firms }\end{array}$ & $\begin{array}{l}\text { Narjess Boubakri, Jean-Claude } \\
\text { Cosset, and Omrane Guedhami }\end{array}$ & Dec. 2001 \\
\hline $\begin{array}{l}\text { No. 418: The European Data Privacy Directive and International } \\
\text { Relations }\end{array}$ & Steven R. Salbu & Dec. 2001 \\
\hline $\begin{array}{l}\text { No. 417: Capital Markets and Capital Allocation: Implications for } \\
\text { Economies in Transition }\end{array}$ & $\begin{array}{l}\text { Artyom Durnev, Randall Morck, } \\
\text { and Bernard Yeung }\end{array}$ & Dec. 2001 \\
\hline $\begin{array}{l}\text { No. 416: Forthcoming in: The Journal of Economic Perspectives, "Data } \\
\text { Watch. Research Data from Transition Economies," 16(2) Feb. } 2002 .\end{array}$ & $\begin{array}{l}\text { Randall K. Filer and Jan } \\
\text { Hanousek }\end{array}$ & Dec. 2001 \\
\hline $\begin{array}{l}\text { No. 415: Forthcoming in: The Journal of Economic Perspectives, } \\
\text { "Transition Economies: Performance and Challenges," 16(2) Feb. } 2002 .\end{array}$ & Jan Svejnar & Dec. 2001 \\
\hline $\begin{array}{l}\text { No. 414: Forthcoming in: The Journal of Economic Perspectives, "The } \\
\text { Great Divide and Beyond: Financial Architecture in Transition," 16(2) } \\
\text { Feb. 2002. }\end{array}$ & Erik Berglof and Patrick Bolton & Dec. 2001 \\
\hline $\begin{array}{l}\text { No. 413: Forthcoming in: The Journal of Economic Perspectives, "The } \\
\text { Political Economy of Transition," 16(2) Feb. } 2002 .\end{array}$ & Gérard Roland & Dec. 2001 \\
\hline $\begin{array}{l}\text { No. 412: The Response of Consumption in Russian Households to } \\
\text { Economic Shocks }\end{array}$ & Steven Stillman & Oct. 2001 \\
\hline No. 411: Mark-ups in Hungarian Corporate Sector & László Halpern and Gábor Körösi & Aug. 2001 \\
\hline No. 410: Economic Development, Legality, and the Transplant Effect & $\begin{array}{l}\text { Daniel Berkowitz, Katarina } \\
\text { Pistor, Jean-Francois Richard }\end{array}$ & Sept. 2001 \\
\hline No. 409: Development Strategy, Viability, and Economic Convergence & Justin Yifu Lin & Oct. 2001 \\
\hline No. 408: Labor Supply, Informal Economy and Russian Transition & Maxim Bouev & May 2001 \\
\hline No. 407: Corporate Governance in China: Then and Now & Cindy Schipani and Liu Junhai & Nov. 2001 \\
\hline No. 406: Entrepreneurship and Post-Socialist Growth & $\begin{array}{l}\text { Daniel Berkowitz and David N. } \\
\text { DeJong }\end{array}$ & Oct. 2001 \\
\hline $\begin{array}{l}\text { No. 405: Forthcoming in: European Economic Review, "Policy Reform } \\
\text { and Growth in Post-Soviet Russia." }\end{array}$ & $\begin{array}{l}\text { Daniel Berkowitz and David N. } \\
\text { DeJong }\end{array}$ & Oct. 2001 \\
\hline $\begin{array}{l}\text { No. 404: Social Policies and Structures: Institutional Frictions and Traps } \\
\text { in the Czech Republic after } 1989\end{array}$ & Jiří Večerník & Nov. 2001 \\
\hline $\begin{array}{l}\text { No. 403: Investment, Efficiency, and Credit Rationing: Evidence from } \\
\text { Hungarian Panel Data }\end{array}$ & Mathilde Maurel & Nov. 2001 \\
\hline $\begin{array}{l}\text { No. 402: Subduing High Inflation in Romania. How to Better Monetary } \\
\text { and Exchange Rate Mechanisms? }\end{array}$ & $\begin{array}{l}\text { Daniel Daianu and Radu } \\
\text { Vranceanu }\end{array}$ & Aug. 2001 \\
\hline $\begin{array}{l}\text { No. 401: The Gender Wage Gap in Bulgaria: A Semiparametric } \\
\text { Estimation of Discrimination }\end{array}$ & Dean Jolliffe & July 2001 \\
\hline
\end{tabular}

